\title{
Commentary: GPR160 De-Orphanization Reveals Critical Roles in Neuropathic Pain in Rodents (Finally, a Receptor for CART Peptide)
}

\author{
Martin O. Job ${ }^{1 *}$ and Michael J. Kuhar ${ }^{2}$ \\ ${ }^{1}$ Department of Biomedical Sciences, Cooper Medical School of Rowan University, Camden, NJ, United States, ${ }^{2}$ Yerkes National \\ Primate Research Center, Emory University, Atlanta, GA, United States
}

Keywords: GPR160, orphan receptor, CART peptide receptor, cocaine-and-amphetamine regulated transcript, GPCR, neurotransmitter

\section{A Commentary on}

GPR160 de-orphanization reveals critical roles in neuropathic pain in rodents by Yosten GLC, Harada CM, Haddock C, Giancotti LA, Kolar GR, Patel R, Gou C, Chen Z, Zhang J, Doyle TM, Dickenson AH, Samson WK, and Salvemini D. (2020). J Clin Invest. 130:2587-92. doi: 10.1172/JCI133270

OPEN ACCESS

Edited by:

Emmanuel Onaivi, William Paterson University,

United States

Reviewed by:

Qing-Rong Liu,

National Institute on Aging $(\mathrm{NIH})$,

United States

Zheng-Xiong Xi,

National Institute on Drug Abuse

(NIDA), United States

*Correspondence: Martin O. Job

job@rowan.edu

Received: 05 August 2021 Accepted: 26 August 2021 Published: 07 October 2021

Citation:

Job MO and Kuhar MJ (2021)

Commentary: GPR160 DeOrphanization Reveals Critical Roles in Neuropathic Pain in Rodents (Finally, a

Receptor for CART Peptide).

Adv. Drug. Alco. Res. 1:10012.

doi: 10.3389/adar.2021.10012
Signaling in rat brainstem via Gpr160 is required for the anorexigenic and antidipsogenic actions of cocaine- and amphetamine-regulated transcript peptide by Haddock CJ, Almeida-Pereira G, Stein LM, Hayes MR, Kolar GR, Samson WK, et al. (2021). Am J Physiol Regul Integr Comp Physiol. 320:R236-49. doi: 10.1152/ajpregu.00096.2020

This commentary focuses on recent publications identifying a likely Cocaine-and-Amphetamine Regulated Transcript (CART) peptide (CARTp) receptor, namely the recently de-orphanized GPR160, some 26 years after the discovery of the CART mRNA. These publications are Yosten et al. [1], and Haddock et al. [2].

\section{BACKGROUND}

The discovery of the CART transcript and peptides implicated CARTp as a neurotransmitter involved in the action of psychostimulants and neuroendocrine regulation [3, 4]. But it became evident that it was involved in many additional physiological processes including body weight and feeding, energy expenditure, physical activity, body temperature, endocrine regulation, drug abuse and reward, pain, stress, hypertension, anxiety and depression, recovery from stroke, and possibly others. There are many reviews and other citations describing the evidence for these effects [5-30]. The general belief was and is that CARTp is an important peptide neurotransmitter. Several peptides derived from proCART are likely active [10, 14, 31].

Following the exciting discoveries of the peptide's involvement in drug abuse $[4,7,10,11,17,30]$ and other processes, a critical need was for the identification and cloning of a CARTp receptor. There was evidence that a receptor existed, and it is briefly as follows. Responses to injections of CARTp were dose-responsive and the active peptide had structural requirements [14, 18, 22, 27, 30-40]. Injections of CARTp increased levels of second messengers, a common post receptor event [20, 21, 
25, 28, 41-43]. Radiolabeled CARTp showed displaceable binding to neuronal cultured cells membranes, although and unusually so, not to adult brain tissue membranes [20, 27, 32, 42]. CARTp binding was altered by Gpp (nh)p - a G-protein binding ligand, and CARTp enhanced the binding of (35)S-GTP gamma S; these and other studies suggested that the receptor was a GPCR coupled to $\mathrm{Gi} / \mathrm{o}[19-21,28,43,44]$. See also the reviews cited at the end of the last paragraph.

\section{RECENT DISCOVERIES}

Given the existing evidence that a CARTp receptor is a GPCR, a reasonable approach to searching for a CART peptide receptor is to examine GPCR orphan receptors, receptors for which there are no known neurotransmitter ligands [29]. In studies of neuropathic pain, Yosten et al [1] found that an orphan receptor, GPR160 played a significant role in neuropathic pain and spinal cord. GPR160 was increased in spinal cord after traumatic nerve injury. Also, inhibition of GRR160 in the spinal cord prevented and reversed neuropathic pain but had no effect on normal pain. They then examined the connection between CARTp and GPR160 using antibodies (ab) and short interfering RNAs (si).

In KATO cancer cells, CARTp-induced cFOS expression and this was blocked by prior depletion of GPR160 using an siGPR160. In PC12 cells expressing GPR160, CARTp stimulated ERK phosphorylation, but prior treatment with si-GPR160 reduced the effect. Also, CARTp co-immunoprecipitated with GPR160 protein indicating the likelihood of a physical interaction in vivo. Another finding was that injection of CARTab mimicked the effects of GPR160 inhibition. A CARTp-induced mechanohypersensitivity was dependent on GPR160. CARTp induced phosphorylation of ERK but this was attenuated with coinjection of GRP160ab. These data showed a functional and physical connection between CARTp and GPR160, at least in neuropathic pain.

Haddock et al [2] studied the CARTp receptor problem in the context of food and water intake. Injection of CARTp into the fourth ventricle reduced food and water intake, and this was prevented by immuno-neutralization of GPR160, again a connection between CARTp and GPR160. A hypothesis of circuitry and cellular localizations was made to provide a possible mechanism for these observations.

\section{REFERENCES}

1. Yosten GLC, Harada CM, Haddock C, Giancotti LA, Kolar GR, Patel R, et al. GPR160 De-orphanization Reveals Critical Roles in Neuropathic Pain in Rodents. J Clin Invest. (2020) 130:2587-92. https://www.jci.org/articles/view/133270

2. Haddock CJ, Almeida-Pereira G, Stein LM, Hayes MR, Kolar GR, Samson WK, et al. Signaling in Rat Brainstem via Gpr160 is Required for the Anorexigenic and Antidipsogenic Actions of Cocaine- and Amphetamine-Regulated Transcript Peptide. Am J Physiol Regul Integr Comp Physiol. (2021) 320: R236-R249. doi:10.1152/ajpregu.00096.2020

3. Vale W, Spiess J, Rivier C, and Rivier J. Characterization of a 41-Residue Ovine Hypothalamic Peptide that Stimulates Secretion of Corticotropin and Betaendorphin. Science (1981) 213:1394-7. doi:10.1126/science.6267699

\section{DISCUSSION}

These findings strongly link the effects of CARTp to binding to an orphan receptor, GPR160. This initial identification of a CARTp receptor is a welcome observation after so many years of searching. Additional studies and confirmation of these findings are needed.

Could there be other CARTp receptors? It seems likely since most neurotransmitters have multiple receptors, and as noted above and elsewhere [45], there are several slightly different CARTps in different species and organs. In the recent studies discussed here, CARTp and GPR160 are implicated in neuropathic pain and food and water intake. Other receptors may be involved with other functions of CARTps.

This discovery will facilitate further research and understanding of the CARTp system in brain and periphery. It will also facilitate screening for small molecule agonists and antagonists, of which some mention has been made [20]. This will be very helpful in further studies of the functions of CARTps and for identifying therapeutic compounds based on CART.

\section{AUTHOR CONTRIBUTIONS}

Both MJ and MK contributed equally to the article. MK wrote the original draft of the article. MJ prepared the final draft of the article for submission.

\section{FUNDING}

This research is supported by the National Institutes of Health's Office of the Director, Office of Research Infrastructure Programs, P51 OD011132. MK also acknowledges support from the Georgia Research Alliance.

\section{CONFLICT OF INTEREST}

The authors declare that the research was conducted in the absence of any commercial or financial relationships that could be construed as a potential conflict of interest.

4. Douglass J, McKinzie A, and Couceyro P. PCR Differential Display Identifies a Rat Brain mRNA that is Transcriptionally Regulated by Cocaine and Amphetamine. J Neurosci (1995) 15(3 II):2471-81. doi:10.1523/ jneurosci.15-03-02471.1995

5. Yosten GLC, Haddock CJ, Harada CM, Almeida-Pereira G, Kolar GR, Stein LM, et al. Past, Present and Future of Cocaine- and Amphetamine-Regulated Transcript Peptide. Physiol Behav (2021) 235:113380. doi:10.1016/j.physbeh.2021.113380

6. Singh A, de Araujo AM, Krieger J-P, Vergara M, Ip CK, and de Lartigue G. Demystifying Functional Role of Cocaine- and Amphetamine-related Transcript (CART) Peptide in Control of Energy Homeostasis: A Twenty-five Year Expedition. Peptides (2021) 140:170534. doi:10.1016/j.Peptides.2021.170534

7. Kuhar MJ, and Job MO. CART Peptide Regulates Psychostimulant-induced Activity and Exhibits a Rate Dependency. J Drug Alcohol Res (2017) 6:1-2. doi:10.4303/jdar/ 236032 
8. Lau J, and Herzog H. CART in the Regulation of Appetite and Energy Homeostasis. Front Neurosci (2014) 8:313. doi:10.3389/fnins.2014.00313

9. Zhang M, Han L, and Xu Y. Roles of Cocaine- and Amphetamine-regulated Transcript in the Central Nervous System. Clin Exp Pharmacol Physiol (2012) 39:586-92. doi:10.1111/j.1440-1681.2011.05642.x

10. Rogge G, Jones D, Hubert GW, Lin Y, and Kuhar MJ. CART Peptides: Regulators of Body Weight, Reward and other Functions. Nat Rev Neurosci (2008) 9:747-58. doi:10.1038/nrn2493

11. Fagergren P, and Hurd Y. CART mRNA Expression in Rat Monkey and Human Brain: Relevance to Cocaine Abuse. Physiol Behav (2007) 92:218-25. doi:10.1016/j.physbeh.2007.05.027

12. Wierup N, and Sundler F. CART is a Novel Islet Regulatory Peptide. Peptides (2006) 27:2031-6. doi:10.1016/j.Peptides.2006.02.011

13. Ekblad E. CART in the Enteric Nervous System. Peptides (2006) 27:2024-30. doi:10.1016/j.Peptides.2005.12.015

14. Stein J, Steiner DF, and Dey A. Processing of Cocaine- and Amphetamineregulated Transcript (CART) Precursor Proteins by Prohormone Convertases (PCs) and its Implications. Peptides (2006) 27:1919-25. doi:10.1016/ j.Peptides.2005.10.028

15. Koylu EO, Balkan B, Kuhar MJ, and Pogun S. Cocaine and Amphetamine Regulated Transcript (CART) and the Stress Response. Peptides (2006) 27: 1956-69. doi:10.1016/j.Peptides.2006.03.032

16. Larsen PJ, and Hunter RG. The Role of CART in Body Weight Homeostasis. Peptides (2006) 27:1981-6. doi:10.1016/j.Peptides.2005.11.027

17. Kuhar MJ. CART Peptides and Drugs of abuse: A review of recent progress. J Drug Alcohol Res (2016) 5:1-6. doi:10.4303/jdar/235984

18. Moffett M, Stanek L, Harley J, Rogge G, Asnicar M, Hsiung H, et al. Studies of Cocaine- and Amphetamine-regulated Transcript (CART) Knockout mice. Peptides (2006) 27:2037-45. doi:10.1016/j.Peptides.2006.03.035

19. Yermolaieva O, Chen J, Couceyro PR, and Hoshi T. Cocaine- and Amphetamine-regulated Transcript Peptide Modulation of Voltage-Gated Ca2+Signaling in Hippocampal Neurons. J Neurosci (2001) 21:7474-80. doi:10.1523/jneurosci.21-19-07474.2001

20. Lin Y, Hall RA, and Kuhar MJ. CART Peptide Stimulation of G ProteinMediated Signaling in Differentiated PC12 Cells: Identification of PACAP 6-38 as a CART Receptor Antagonist. NeuroPeptides (2011) 45:351-8. doi:10.1016/ j.npep.2011.07.006

21. Lakatos A, Prinster S, Vicentic A, Hall RA, and Kuhar MJ. Cocaine- and Amphetamine-regulated Transcript (CART) Peptide Activates the Extracellular Signal-regulated Kinase (ERK) Pathway in AtT20 Cells via Putative G-protein Coupled Receptors. Neurosci Lett (2005) 384:198-202. doi:10.1016/j.neulet.2005.04.072

22. Vicentic A, Lakatos A, and Jones D. The CART Receptors: Background and Recent Advances. Peptides (2006) 27:1934-7. doi:10.1016/j.Peptides.2006.03.031

23. Samson WK, Salvemini D, and Yosten GLC. Overcoming Stress, Hunger, and Pain: Cocaine- and Amphetamine-Regulated Transcript Peptide's Promise. Endocrinology (2021) 162:162. doi:10.1210/endocr/bqab108

24. Abels M, Riva M, Bennet H, Ahlqvist E, Dyachok O, Nagaraj V, et al. CART is Overexpressed in Human Type 2 Diabetic Islets and Inhibits Glucagon Secretion and Increases Insulin Secretion. Diabetologia (2016) 59:1928-37. doi:10.1007/s00125-0164020-6

25. Brennan DJ, O'Connor DP, Laursen H, Mcgee SF, Mccarthy S, Zagozdzon R, et al. The Cocaine- and Amphetamine-regulated Transcript Mediates Ligand-independent Activation of ERa, and is an Independent Prognostic Factor in Node-negative Breast Cancer. Oncogene (2012) 31:3483-94. doi:10.1038/onc.2011.519

26. Ahmadian-Moghadam H, Sadat-Shirazi M-S, and Zarrindast M-R. Cocaineand Amphetamine-regulated Transcript (CART): A Multifaceted NeuroPeptide. Peptides (2018) 110:56-77. doi:10.1016/j.Peptides.2018.10.008

27. Subhedar NK, Nakhate KT, Upadhya MA, and Kokare DM. CART in the Brain of Vertebrates: Circuits, Functions and Evolution. Peptides (2014) 54:108-30. doi:10.1016/j.Peptides.2014.01.004

28. Nagelová V, Pirník Z, Železná B, and Maletínská L. CART (Cocaine- and Amphetamine-regulated Transcript) Peptide Specific Binding Sites in PC12 Cells have Characteristics of CART Peptide Receptors. Brain Res (2014) 1547: 16-24. doi:10.1016/j.brainres.2013.12.024

29. Davenport AP, Alexander SPH, Sharman JL, Pawson AJ, Benson HE, Monaghan $\mathrm{AE}$, et al. International union of Basic and Clinical Pharmacology. LXXXVIII. g
Protein-Coupled Receptor List: Recommendations for new Pairings with Cognate Ligands. Pharmacol Rev (2013) 65:967-86. doi:10.1124/pr.112.007179

30. Meng Q, Kim H-C, Oh S, Lee Y-M, Hu Z, and Oh K-W. Cocaine- and Amphetamine-Regulated Transcript (CART) Peptide Plays Critical Role in Psychostimulant-Induced Depression. Biomolecules Ther (2018) 26:425-31. doi:10.4062/biomolther.2018.141

31. Thim L, Kristensen P, Nielsen PF, Wulff BS, and Clausen JT. Tissue-Specific Processing of Cocaine- and Amphetamine-regulated Transcript Peptides in the Rat. Proc Natl Acad Sci (1999) 96:2722-7. doi:10.1073/PNAS.96.6.2722

32. Wierup N, Richards WG, Bannon AW, Kuhar MJ, Ahrén B, and Sundler F. CART knock out mice have Impaired Insulin Secretion and Glucose Intolerance, Altered Beta Cell Morphology and Increased Body Weight. Regul Peptides (2005) 129:203-11. doi:10.1016/J.REGPEP.2005.02.016

33. Miraglia del Giudice E, Santoro N, Fiumani P, Dominguez G, Kuhar MJ, and Perrone L. Adolescents Carrying a Missense Mutation in the CART Gene Exhibit Increased Anxiety and Depression. Depress Anxiety (2006) 23:90-2. doi:10.1002/DA.20156

34. Salinas AG, Nguyen CTQ, Ahmadi-Tehrani D, and Morrisett RA. Reduced Ethanol Consumption and Preference in Cocaine- and Amphetamineregulated Transcript (CART) Knockout Mice. Addict Biol (2014) 19: 175-84. doi:10.1111/J.1369-1600.2012.00475.X

35. Maixnerová J, Hlaváček J, Blokešová D, Kowalczyk W, Elbert T, Šanda M, et al. Structure-Activity Relationship of CART (Cocaine- and Amphetamineregulated Transcript) Peptide Fragments. Peptides (2007) 28:1945-53. doi:10.1016/J.PEPTIDES.2007.07.022

36. Blechová M, Nagelová $\mathrm{V}$, Žáková L, Demianová Z, Železná B, and Maletínská L. New Analogs of the CART Peptide with Anorexigenic Potency: The Importance of Individual Disulfide Bridges. Peptides (2013) 39:138-44. doi:10.1016/j.Peptides.2012.09.033

37. Maletínská L, Maixnerová J, Matyšková R, Haugvicová $\mathrm{R}$, Šloncová E, Elbert T, et al. Cocaine- and Amphetamine-regulated Transcript (CART) Peptide Specific Binding in Pheochromocytoma Cells PC12. Eur J Pharmacol (2007) 559:109-14. doi:10.1016/j.ejphar.2006.12.014

38. Pražienková V, Marek A, and Maletínská L. Iodination of CART(61-102) Peptide: Preserved Binding and Anorexigenic Activity in Mice. J Label Compd Radiopharm (2021) 64:61-4. doi:10.1002/JLCR.3871

39. Smith KL, Gardiner JV, Ward HL, Kong WM, Murphy KG, Martin NM, et al. Overexpression of CART in the PVN Increases Food Intake and Weight Gain in Rats. Obesity (Silver Spring) (2008) 16:2239-44. doi:10.1038/OBY.2008.366

40. Asnicar MA, Smith DP, Yang DD, Heiman ML, Fox N, Chen Y-F, et al. Absence of Cocaine- and Amphetamine-regulated Transcript Results in Obesity in Mice Fed a High Caloric Diet. Endocrinology (2001) 142: 4394-400. doi:10.1210/ENDO.142.10.8416

41. Vrang N, Tang-Christensen M, Larsen PJ, and Kristensen P. Recombinant CART Peptide Induces c-Fos Expression in Central Areas involved in Control of Feeding Behaviour. Brain Res (1999) 818:499-509. doi:10.1016/S0006-8993(98)01349-3

42. Smedh U, Scott KA, and Moran TH. Fourth Ventricular CART Peptide Induces c-fos in the area Postrema and Nucleus of the Solitary Tract via a CRF-receptor Dependent Mechanism. Neurosci Lett (2015) 609:124-8. doi:10.1016/J.NEULET.2015.10.028

43. Somalwar AR, Choudhary AG, Sharma PR, B. N, Sagarkar S, Sakharkar AJ, et al. Cocaine- and Amphetamine-regulated Transcript Peptide (CART) Induced Reward Behavior is mediated via Gi/o dependent Phosphorylation of PKA/ERK/CREB Pathway. Behav Brain Res (2018) 348:9-21. doi:10.1016/j.bbr.2018.03.035

44. Vicentic A, Lakatos A, and Kuhar MJ. CART (Cocaine- and Amphetamine-regulated Transcript) Peptide Receptors: Specific Binding in AtT20 Cells. Eur J Pharmacol (2005) 528:188-9. doi:10.1016/J.EJPHAR.2005.11.041

45. Kuhar MJ, and Yoho LL. CART Peptide Analysis by Western Blotting. Synapse (1999) 33:163-71. doi:10.1002/(sici)1098-2396(19990901)33:3<163:aid-syn1>3.0.co10.1002/ (sici)1098-2396(19990901)33:3<163:aid-syn1>3.0.co;2-t2-t

Copyright $\odot 2021$ Job and Kuhar. This is an open-access article distributed under the terms of the Creative Commons Attribution License (CC BY). The use, distribution or reproduction in other forums is permitted, provided the original author(s) and the copyright owner(s) are credited and that the original publication in this journal is cited, in accordance with accepted academic practice. No use, distribution or reproduction is permitted which does not comply with these terms. 